\title{
Process Optimization of Aonla Jam Using Response Surface Methodology
}

\author{
Parveen Kumari and B.S. Khatkar* \\ Department of Food Technology, Guru Jambheshwar University of Science and Technology, \\ Hisar-125001, India \\ *Corresponding author
}

\begin{tabular}{|l|l|}
\hline \multicolumn{2}{c}{ A B S T R A C T } \\
\cline { 2 - 2 } \begin{tabular}{l}
\hline Key words \\
$\begin{array}{l}\text { Aonla, Sugar, Response, } \\
\text { Model, Adhesivenss, } \\
\text { Significant }\end{array}$
\end{tabular} & $\begin{array}{l}\text { Response surface methodology tool was used to assess ingredient interaction and } \\
\text { model taking into account their respective responses for preparing aonla jam. } \\
\text { Model capable of predicting the quality of aonla products were derived. Jam was } \\
\text { prepared using aonla pulp, sugar and citric acid and response observed were gel } \\
\text { strength, rupture force, adhesiveness and overall acceptability. The F-values for } \\
\text { models of gel strength, rupture force, adhesiveness and overall acceptability } \\
\text { Article Info }\end{array}$ \\
\hline $\begin{array}{l}\text { Accepted: } \\
\text { 20 September 2018 } \\
\text { Available Online: } \\
\text { 10 October 2018 }\end{array}$ & $\begin{array}{l}\text { significant }(\mathrm{p}<0.001) \text { while the lack of fit was non-significant for all models event } \\
\text { at 95\% level. }\end{array}$ \\
\hline \hline
\end{tabular}

\section{Introduction}

Aonla fruit is a rich source of ascorbic acid, minerals and other nutrients along with tannin and phenols which contribute to its antioxidant activity and other therapeutic values. Aonla is an important constituent in different Ayurvedic preparations such as triphala, chyavanprash, amrit kalash and rasayana (Rajkumar et al., 2001). As the table value of aonla fruit is limited due to high acidity and astringent nature. Therefore, processing of fruit is required into different products. Stability of vitamin $\mathrm{C}$ in aonla products after processing is a matter of interest for fruit processing industries (Pathak et al., 2003). So the present study was planned to standardize aonla jam formulation and to study quality parameters as well as phytochemicals analysis.

\section{Materials and Methods}

\section{Aonla jam}

Aonla jam was prepared using variety Chakaiya as it is a good source of pectin and acid. Optimization of formula ingredient was done using RSM (response surface methodology). Physico-chemical analysis of variety Chakaiya reported by Parveen and Khatkar, (2015) supported that it was suitable for jam preparation. An optimum level of sugar, pectin and acid is required for the proper setting of jam. Role of sugar is to bind water, to provide proper texture and flavor with reducing the microbial load. Sugar with citric acid and pectin form a gel to give texture to jam (Patten, 2001). Citric acid by reducing the inversion of sugars avoids the chances of 
crystallization and also helps in pectin extraction (Tim et al., 2012). On the basis of responses, solution was predicted by the software. Runs were carried out for solution and results were analyzed against predicted value.

\section{Results and Discussion}

\section{Model fitness}

The experimental design sheet and their response values obtained were subjected to model fitness and fitness of model was judged on the basis of F-values (Table 1). The Fvalues for models of gel strength, rupture force, adhesiveness and overall acceptability (209.29, 49.85, 55.58 and 76.18 respectively) was observed to be highly significant $(\mathrm{p}<0.001)$ while the lack of fit was noted to be non-significant for all models event at $95 \%$ level. This value suggested that model used for study adequately represented data for response studied. The insignificant $(p>0.1)$ model terms were eliminated using backward regression and predication equation was derived for all the response studied (Table 2).

\section{Effect of ingredients on gel strength}

Gel strength is an important parameter for the jam quality as it imparts proper texture and spreadability to jam. A quadratic model $\left(\mathrm{R}^{2}\right)$ was observed for gel strength with $\mathrm{B}, \mathrm{AB}, \mathrm{BC}$, $\mathrm{B}^{2}$ and $\mathrm{C}^{2}$ being the significant terms. It was observed that sugar was the main factor that significantly affected the gel strength in aonla jam. The variation in gel strength with aonla pulp and sugar is presented in Figure 1 (A) and with citric acid and aonla pulp shown in Figure 1 (B). As depicted in the response surface graph I (A) and (B), gel strength sharply increased with increase in sugar while increase was less with citric acid. Figure 1 (B) shows that gel strength was higher at sugar level $65 \mathrm{~g}$ and aonla pulp $100 \mathrm{~g}$.

\section{Effect of ingredients on rupture force}

ANOVA analysis for rupture forces of aonla jam indicated that linear model $(\mathrm{p}<0.05)$ $(p<0.001)$ and quadratic model $(p<0.01)$ of aonla pulp, sugar and citric acid significantly affected the response. All the ingredients affected rupture force in linear terms. As depicted from Figure 2 (A) with increase in aonla pulp increase was noted in rupture force while for citric acid at $0.35 \mathrm{~g}$ rupture force was maximum. The equation for rupture force is shown in Table 2 in coded terms. From Figure 2 (B) it is clear that a sharp increase was noted in rupture force with increase in sugar concentration while their interactive effect was not observed. It might be due to formation of gel network at optimum concentration of formula ingredients and further not affected by increasing the value.

\section{Effect of formula ingredients on adhesiveness}

As depicted in Table 1 adhesiveness of aonla jam is significantly $(\mathrm{p}<0.001)$ affected by aonla pulp, sugar and their interactive effect while the effect of citric acid was nonsignificant. Coefficient of determination $\left(\mathrm{R}^{2}\right)$ was found to be 0.961 for adhesiveness. The predicted value of $\mathrm{R}^{2}(0.946)$ is in reasonable agreement with adjusted $\mathrm{R}^{2}$ (0.926). Interactive effect of aonla pulp and sugar on adhesiveness is presented in Figure 3 (A).

Adhesiveness was decreased with increase in aonla pulp upto $104 \mathrm{~g}$ after that increase was observed while with increase in sugar concentration adhesiveness was increased. Adhesiveness was found optimum at $67 \mathrm{~g}$ sugar level and $102 \mathrm{~g}$ aonla pulp after that increase was not noted. It might be due to utilization of aonla pulp, sugar and citric acid in formation of gel network and further higher level of ingredients increased the adhesiveness. 
Table.1 Analysis of variance for different response models

\begin{tabular}{|c|c|c|c|c|}
\hline Source $^{\mathrm{a}}$ & GS & RF & Ad & $\mathbf{O A}$ \\
\hline Model fitted & Quadratic & Quadratic & Quadratic & Quadratic \\
\hline \multicolumn{5}{|c|}{ F value } \\
\hline Model & $209.29 * * *$ & $49.85 * * *$ & $55.58 * * *$ & $76.18 * * *$ \\
\hline $\mathbf{A}$ & $0.11 \mathrm{NS}$ & $8.05^{*}$ & $41.75 * * *$ & $31.95 * * *$ \\
\hline $\mathbf{B}$ & $1019.55 * * *$ & $135.90 * * *$ & $60.12 * * *$ & $220.18 * * *$ \\
\hline$\overline{\mathbf{C}}$ & $1.21 \mathrm{NS}$ & $5.60 *$ & 4.64 NS & $0.5 \mathrm{NS}$ \\
\hline $\mathbf{A B}$ & $35.87 * * *$ & - & $40.92 * * *$ & $156.02 * * *$ \\
\hline $\mathbf{B C}$ & $27.78 * * *$ & - & - & $42.19 * * *$ \\
\hline $\mathbf{A C}$ & - & - & - & $6.24^{*}$ \\
\hline$A^{2}$ & - & - & $130.48 * * *$ & - \\
\hline $\mathrm{B}^{2}$ & $254.90 * * *$ & - & - & - \\
\hline $\mathrm{C}^{2}$ & $106.19 * * *$ & - & - & - \\
\hline Lack of Fit & $1.49 \mathrm{NS}$ & $0.38 \mathrm{NS}$ & $0.57 \mathrm{NS}$ & $1.72 \mathrm{NS}$ \\
\hline $\mathbf{R}^{2}$ & 0.993 & 0.920 & 0.961 & 0.978 \\
\hline Adjusted $\mathbf{R}^{2}$ & 0.989 & 0.901 & 0.946 & 0.965 \\
\hline Predicted $\mathbf{R}^{2}$ & 0.967 & 0.876 & 0.926 & 0.918 \\
\hline
\end{tabular}

* Significant at $P<0.05$; ** significant at $P<0.01$; *** significant at $P<0.001 . \mathrm{A}=$ Aonla pulp $(\mathrm{g}), \mathrm{B}=\mathrm{Sugar}(\mathrm{g}), \mathrm{C}=$ Citric acid (g), GS= Gel strength (g), RF= Rupture force (g), Ad= Adhesiveness (g), OA= Overall acceptability score

Table.2 Predicted equations for different responses

\section{Predicted equations for different responses in terms of coded factors ${ }^{\text {a }}$}

Gel strength $=22.7474+0.05 * \mathrm{~A}+4.7125 * \mathrm{~B}-0.1625 * \mathrm{C}+1.25 * \mathrm{AB}-1.1 * \mathrm{AC}+3.24342 *$ $\mathrm{B}^{\wedge} 2+2.09342 * \mathrm{C}^{\wedge} 2$

Rupture force $=47.2471+2.1875 * \mathrm{~A}+\mathbf{8 . 9 8 7 5} * \mathrm{~B}-1.825 * \mathrm{C}$

Adhesiveness $=-0.701111-0.0375 * \mathrm{~A}-0.045 * \mathrm{~B}+0.0125 * \mathrm{C}-0.0525 * \mathrm{AB}+0.0911111 * \mathrm{~A}^{\wedge} 2$

Overall acceptability $=5.98824-0.2 * A+0.525 * B-0.025 * C+0.625 * A B-0.125 * A C-0.325$ $* \mathrm{BC}$

${ }^{\mathrm{a}} \mathrm{GS}=$ Gel strength, $\mathrm{RF}=$ Rupture force, $\mathrm{Ad}=$ Adhesiveness, $\mathrm{OA}=$ Overall acceptability score

Table.3 Optimized ingredient level for aonla jam

\begin{tabular}{|l|l|l|l|l|l|l|l|l|}
\hline Number & $\begin{array}{l}\text { Aonla } \\
\text { pulp }\end{array}$ & Sugar & $\begin{array}{l}\text { Citric } \\
\text { acid }\end{array}$ & $\begin{array}{l}\text { Gel } \\
\text { force }\end{array}$ & $\begin{array}{l}\text { Rupture } \\
\text { force }\end{array}$ & Adhesiveness & Sensory & Desirability \\
\hline $\mathbf{1}$ & $\mathbf{9 5 . 9 2 9}$ & $\mathbf{6 6 . 2 0 7}$ & $\mathbf{0 . 5 0 0}$ & $\mathbf{2 8 . 0 0 0}$ & $\mathbf{4 9 . 0 0 3}$ & $\mathbf{- 0 . 6 7 0}$ & $\mathbf{6 . 0 6 8}$ & $\mathbf{0 . 8 4 2}$ \\
\hline $\mathbf{2}$ & 95.943 & 66.060 & 0.500 & 27.937 & 48.931 & -0.670 & 6.069 & 0.842 \\
\hline $\mathbf{3}$ & 95.966 & 65.836 & 0.500 & 27.842 & 48.821 & -0.670 & 6.070 & 0.842 \\
\hline $\mathbf{4}$ & 95.994 & 65.552 & 0.500 & 27.724 & 48.681 & -0.670 & 6.070 & 0.842 \\
\hline $\mathbf{5}$ & 96.032 & 65.190 & 0.500 & 27.574 & 48.503 & -0.670 & 6.071 & 0.842 \\
\hline
\end{tabular}


Table.4 Predicted and actual response values at optimum level of ingredients

\begin{tabular}{|l|l|l|}
\hline Response & Predicted value & Actual value \\
\hline Gel strength & 28.00 & $27.32 \pm 0.43$ \\
\hline Rupture force & 49.00 & $52.08 \pm 0.10$ \\
\hline Adhesiveness & -0.67 & $-0.63 \pm 0.04$ \\
\hline Overall acceptability & 6.06 & $7.57 \pm 0.12$ \\
\hline
\end{tabular}

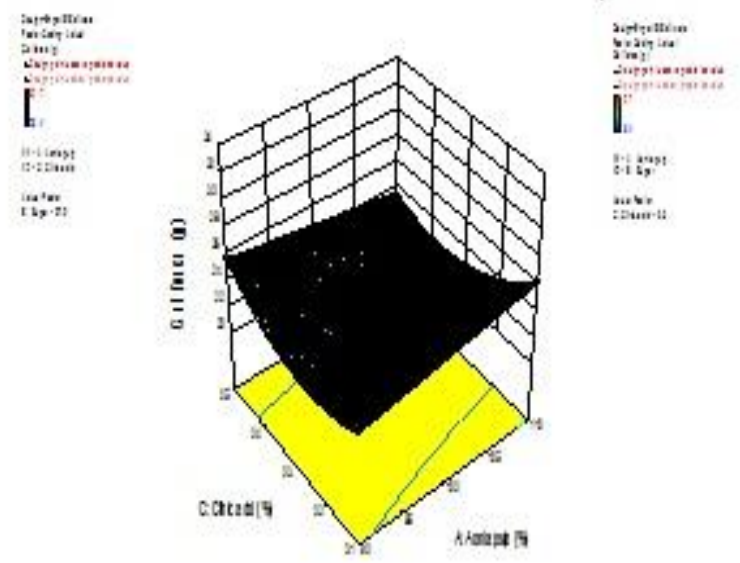

(A)

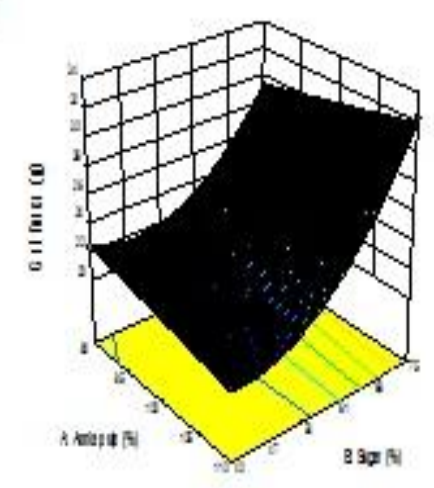

(B)

Fig. I. Effect of (A) aonla pulp \& sugar (B) citric acid \& aonla pulp on gel strength

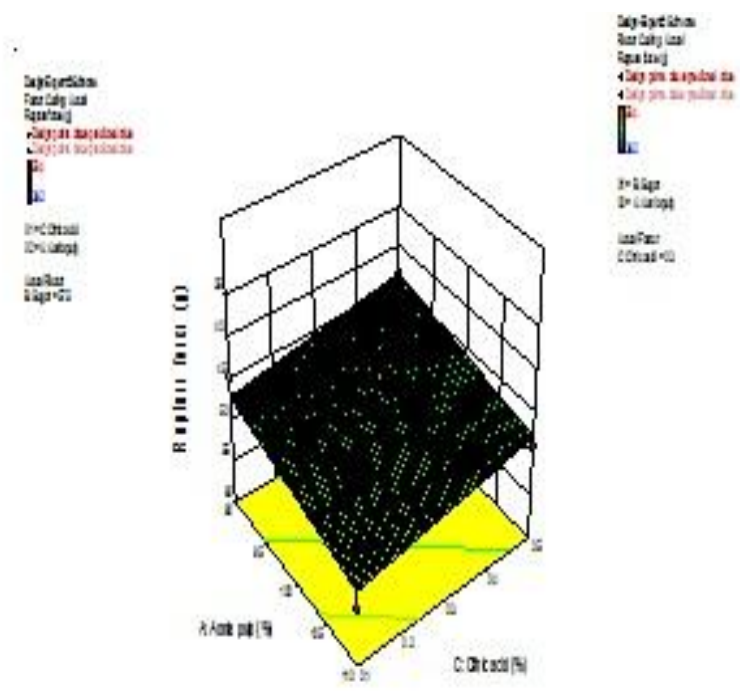

(A)

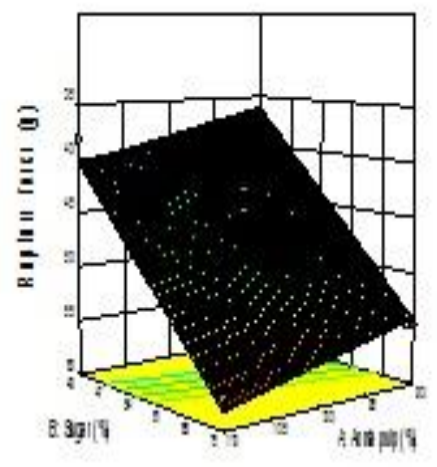

(B)

Fig I. Effect of (A) citric acid \& aonla pulp (B) aonla pulp \& sugar on rupture force 


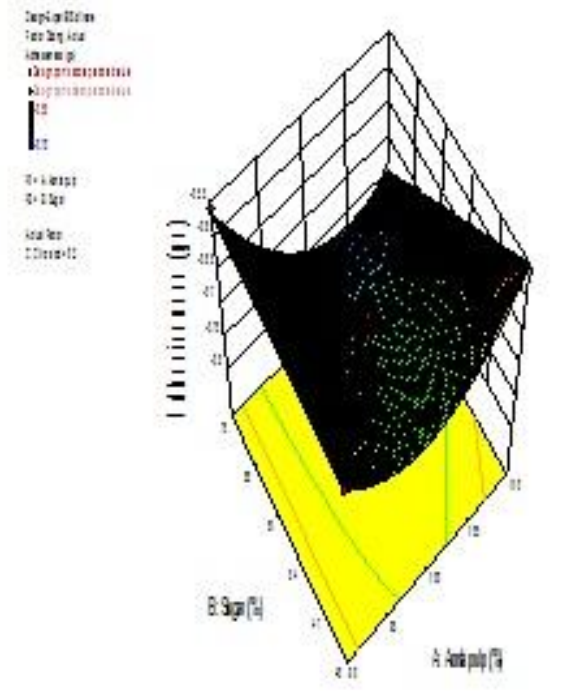

(A)

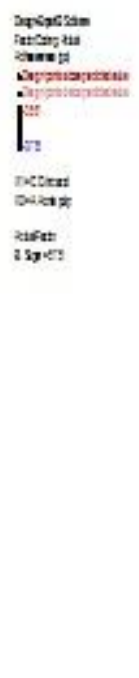

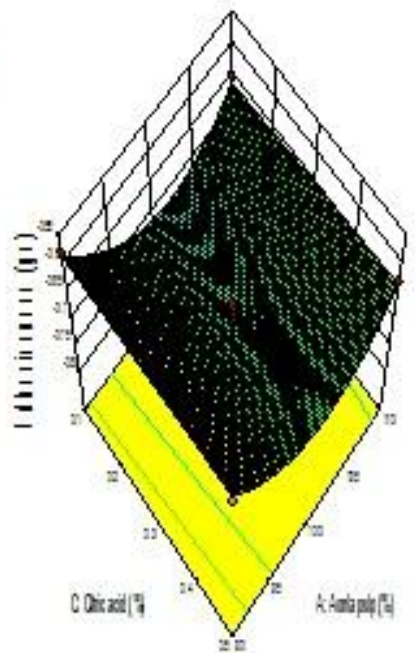

(B)

Fig III. Effect of (A) aonla pulp \& sugar (B) citric acid \& aonla pulp on adhesiveness

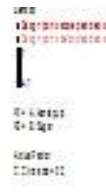

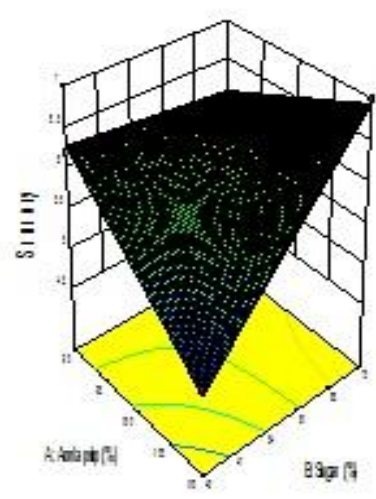

(A)
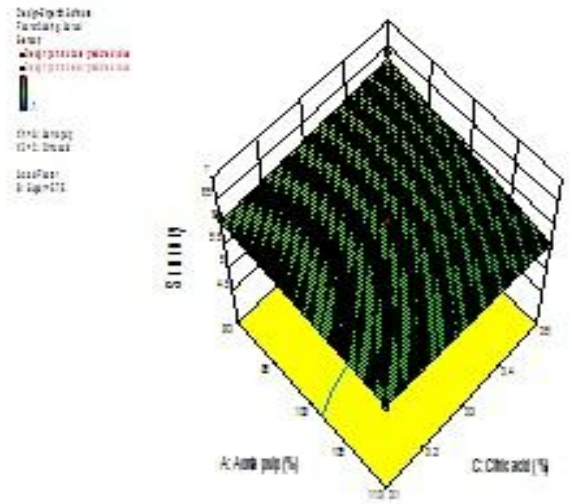

(B)
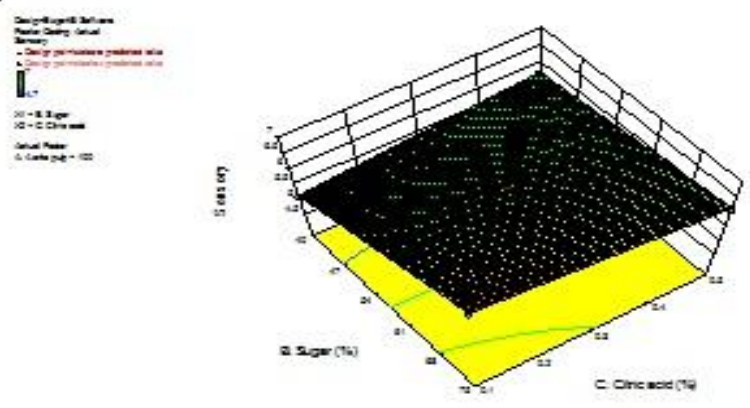

(C)

Fig IV, Effect of (A) aonla pulp \& sugar (B) citric acid \& aonla pulp (C) sugar \& citric acid on $\mathrm{OA}$ 
Effect of formula ingredients on overall acceptability

The results pertaining to overall acceptability are presented in Table 1. The model developed for overall acceptability of aonla jam scored on formula ingredients, viz. sugar and aonla pulp gave an indication as to how these variables should be related. ANOVA analysis showed that aonla pulp, sugar and their interaction significantly affected the OA while citric acid with aonla pulp and sugar showed significant effect on OA of aonla jam. Coefficient of determination $\left(\mathrm{R}^{2}\right)$ was found to be 0.978 . The predicted value for $R^{2}(0.965)$ was in close agreement with adjusted value to $\mathrm{R}^{2}(0.918)$. Figure 4 (A) shows the significant interaction between aonla pulp and sugar for OA. An increase was observed in OA of aonla jam with increase in sugar. Similar trend was reported in sensory score with increase in sugar concentration by Jayabalan and Karthikeyan et al., (2013). Equation for OA in coded term is given in Table 2.

\section{Optimization of formula ingredients for jam}

Numerical and graphical optimization was done of formula ingredients for preparing of aonla jam. The desired level for each response and ingredient was selected. Values for gel strength, rupture force was targeted and for overall acceptability was set to maximum. Higher value of rupture force and gel strength is not desirable as it could decrease the spread ability of jam. After setting value for ingredients and responses, optimized level obtained is presented in Table 3. The adequacy of predicted model values were justified by analyzing the prepared model using optimized level of formula ingredients. The results observed showed that the values of experimental data were close to predicted values (Table 4). Thus optimized level of ingredient is validated. From the study it was concluded that statistical tool response surface methodology used for aonla jam optimization could serve as a model to formulate aonla jam. The optimized level of formula ingredients like aonla pulp, sugar and citric acid for making aonla jam were $95.92 \mathrm{~g}$, $66.20 \mathrm{~g}$ and $0.5 \mathrm{~g}$ and software predicted response values were in close agreement with studied experimental values. Further research are required on aonla supplementation into different fruits products to enhance their nutritional value as well as to increase the table value of aonla, as it is highly astringent in taste

\section{References}

Jayabalan, K. and Karthikeyan, C. 2013. Optimization of ingredients for sensory evaluation of aloe-vera jam preparation using response surface methodology (RSM). International Journal of Engineering Research and Applications 3(1):1224-1234.

Parveen, K. and Khatkar B.S. 2015 Physicochemical properties and nutritional composition of aonla (Emblica officinalis) varieties. International Food Research Journal 22: 2358-2363.

Pathak, R.K., Pandey, D., Mishra, A.K., Haseeb, M. and Tondon, D.K. 2003. The amla. Central Institue for Subtropical Horticulture, Lucknow.

Patten, M. 2001. Basics In: Jams, Preserves and Chutneys. Handbook (2004 reprint ed.) Grub street books. (ISBN 1902304721).

Rajkumar, N.V., Therese, M. and Kutttan, R. 2001. Emblica officinalis fruits afford protection against experimental gastric ulcers in rats. Pharmaceutical Biology 39:375-380

Tim, E.K. 2012. Edible Medicinal and NonMedicinal Plants. $1^{\text {st }}$ edn. (4) fruits. Springer, Netherland.

\section{How to cite this article:}

Parveen Kumari and Khatkar, B.S. 2018. Process Optimization of Aonla Jam Using Response Surface Methodology. Int.J.Curr.Microbiol.App.Sci. 7(10): 2628-2633.

doi: https://doi.org/10.20546/ijcmas.2018.710.305 